\title{
SALIVARY BIOMARKERS FOR MONITORING THE COURSE OF CANCER DEVELOPMENT - REAL PERSPECTIVES
}

\section{WYKORZYSTANIE BIOMARKERÓW W ŚLINIE W MONITOROWANIU PRZEBIEGU CHORÓB NOWOTWOROWYCH - REALNE PERSPEKTYWY}

\author{
Magdalena Karolina Potempa-Jeziorowska ${ }^{1(\mathrm{~A}, \mathrm{D}, \mathrm{E}, \mathrm{F})}$ \\ ${ }^{1}$ Doctoral Studies Centre, Department of Descriptive and Topographic Anatomy, \\ Faculty of Medical Sciences in Zabrze, Medical University of Silesia, Katowice, Poland
}

\begin{abstract}
Authors' contribution Wkład autorów:

A. Study design/planning zaplanowanie badań

B. Data collection/entry zebranie danych

C. Data analysis/statistics dane - analiza i statystyki D. Data interpretation interpretacja danych E. Preparation of manuscript przygotowanie artykułu F. Literature analysis/search wyszukiwanie i analiza literatury G. Funds collection zebranie funduszy
\end{abstract}

Tables: 0

Figures: 0

References: 39

Submitted: 2020 Apr 3

Accepted: 2020 Jun 22

\section{Summary}

Recently, the diagnostic use of saliva in medicine has become a major goal for many researchers. There are many advantages of using saliva diagnostics. Its drawing is non-invasive, painless, quickly repeated, and straightforward. Its diagnostic potential has been demonstrated, in particular for infectious diseases and diseases of the oral cavity. Because of the unabated frequency of occurrence of malignant neoplastic diseases, especially in seniors, this paper aims at presenting an overview of chosen studies that have used saliva in the diagnostic and monitoring of selected malignant diseases. The potential use of saliva in the diagnosis of early-stage lung cancer, by detecting genetic material in saliva and analysis of characteristic mutations of the EGFR gene, has been described. Additionally, prostate cancer can be detected by positive identification of microRNA markers in saliva. Evaluation of PSA concentrations in saliva has also been carried out and obtained results were correlated with blood concentrations. There are also reports concerning the Ca15-3 marker in the saliva in women with breast cancer. The evaluation of lung cancer resistance protein in the saliva of these patients has also been investigated. The results of the cited studies are promising and give hope for the potential use for salivary diagnosis of these cancers.

Keywords: saliva, lung cancer, prostate cancer, breast cancer, pancreatic cancer

\section{Streszczenie}

W ostatnich latach diagnostyczne wykorzystanie śliny $w$ medycynie stało sie celem naukowym dla wielu badaczy. Ślina jako biologiczny materiał diagnostyczny ma wiele zalet: jej pobranie jest małoinwazyjne, niebolesne, szybko powtarzalne i łatwe. Udowodniono jej potencjał diagnostyczny przede wszystkim w chorobach infekcyjnych i jamy ustnej. Ze względu na niesłabnącą częstość występowania nowotworów złośliwych wśród populacji osób w starszym wieku, niniejsza praca ma na celu przedstawić przegląd wybranych badań naukowych wykorzystujących ślinę $w$ diagnostyce oraz monitorowaniu wybranych chorób nowotworowych. Opisano potencjalne wykorzystanie śliny w rozpoznaniu wczesnego stadium raka płuca dzięki detekcji w ślinie materiału genetycznego i analizie charakterystycznych mutacji genu kodującego białko EGFR. Realną perspektywą w raku prostaty jest wykrywanie w ślinie wybranych mikroRNA. Dokonuje się także oceny stężenia antygenu PSA w ślinie, a otrzymane wyniki analizuje się względem jego stężenia we krwi. Istnieje wiele doniesień na temat oznaczeń antygenu Ca15-3 w ślinie wśród kobiet z rakiem piersi. Dokonuje się także oceny białka oporności raka płuc w ślinie u tych chorych. Wyniki przytoczonych badań są obiecujące oraz dają nadzieję na możliwość zastosowania wczesnej diagnostyki tych nowotworów.

Słowa kluczowe: ślina, rak płuca, rak prostaty, rak piersi, rak trzustki

\section{Introduction}

Over the last years, the use of saliva as biological material in medical sciences becomes more and more popular. Saliva constitutes a natural digestive secretion of the major and minor salivary glands. Functions of saliva are not limited to its role in the oral cavity, where it helps form the food morsel as well as participates in articulation and sensing taste. Moreover, it dampens the surface of teeth and mucous membrane of the oral cavity and protects them from harmful factors. It also forms the initial digestion of carbohydrates in the oral cavity, contains amylase, which decomposes maltose to dextrin. Due to the large content of immunologically active 
substances (e.g., lactoferrin, defensin, immunoglobulin), saliva is also a vital, immunological "first line of defense" of the organism. Compounds produced outside the gland, i.e., in the blood where they are more concentrated, can also be found in saliva. This fact is diagnostically significant. The transport takes place intracellularly. They are transferred from plasma to saliva in the course of diffusion, according to the concentration gradient [1]. The basic secretion of saliva oscillates from 0.33 to $0.55 \mathrm{ml} / \mathrm{min}$ and depends on age, gender, and gland stimulation. In the case of the presence of the secretory stimulus, the secretion may increase even to $1.5-2.3 \mathrm{ml} / \mathrm{min}$. The autonomous system controls this process. Apart from water, which constitutes the majority, i.e., $95-98 \%$ of saliva, its composition is diversified. It includes organic components (e.g., blood serum proteins, immunoglobulins, blood group substances, mucin, growth factors, hormones) and non-organic (cations and anions). Substances in saliva may also be categorized into primarily produced in the salivary gland and outside of it [2].

Many advantages are noticed while analyzing saliva as a diagnostic material. Its collection is simple for the patient as well as the diagnostician, does not require a particular procedure. I can also be quickly and easily repeated and significantly less invasive than collecting a blood sample. It is also completely pain-free. The procedure of saliva sample collection is low-cost, and the biological material can be stored easily. The collection of saliva samples does not require the engagement of additional staff. The patient can collect the sample and deliver it to the laboratory within a week. The disadvantage of this method is the lack of established norms for laboratory marking in saliva, the dependence of the obtained concentration on the method of collection, and low recurrence of results. Additionally, in the case of the coexisting oral cavity or systemic diseases, the obtained results may be highly variable [3]. The diagnostic potential of saliva was proven first and foremost in infectious diseases. Serological diagnostics is performed on saliva in which many antibodies specific for infections with a particular viral or bacterial pathogen. So far, it is the major qualitative, not quantitative marker. Tests detecting genetic material of viruses or selected antigens are available. Good effects in diagnostic of the subsequent infections were demonstrated: Helicobacter pylori, hepatitis A, B, and C as well as HIV [4-7]. The diagnostic of the latter is a good example presenting the clinical usefulness of diagnostic in saliva. Equal sensitivity and specificity in the anti-protein epitope in saliva, urine, or plasma were found $[8,9]$.

Malignant cancers constitute a growing health, social, and economic problem for Polish society. According to data collected in 2017, for 100,000 Poles, 429 were diagnosed with neoplasm. Malignant cancers constitute the second cause of death in Poland. According to data processed by Narodowy Rejestr Nowotworów (the National Cancer Register) in 2017, they were the cause of $26.3 \%$ of deaths among men and $23.1 \%$ women. Still, the diagnostic procedure is commenced too late when the malignancy is advanced. Cancers which most frequently occur in Polish men include (in 2017) the following: prostate cancer (19.7\%), lung cancer (16.7\%), and colon cancer $(7.1 \%)$. The most frequently occurring cancers in women are breast cancer $(22.5 \%)$, lung cancer (9.4\%), and endometrial cancer (7.3\%) [10]. This paper aims at presenting scientific reports on the subject of the potential of saliva in attempts at diagnostic and monitoring of lung, prostate, breast, and pancreatic cancer.

\section{Lung cancer}

The early-stage diagnostic of lung cancer is challenging due to symptoms of the tumor being non-specific or its initial stage being asymptomatic. Currently, selected genetic biomarkers are studied, which clinically are predictive or prognostic indicators in selected groups of the population. Some of them may also be grasping points for targeted therapy. Due to new diagnostic methods, it is possible to detect mutations of Epidermal Growth Factor Receptor (EGFR) in body fluids, including saliva. Mutations located within exons 18-21, which code intracellular domains of the receptor with active tyrosine kinase, are the primary mutations within EGFR in lung cancer. The cause continuous stimulation of kinase and transferring a signal to further proliferation into the cell $[11,12]$. Activating mutations in the EGFR gen are characteristic, especially to non-small cell lung cancer (NSCLC). They occur in around 10-15\% of patients with NSCLC in North America and Europe, as well as 30-35\% of patients in Japan and East Asia. Independently from the race, activating mutations occur more frequently in women, non-smokers, and people with NSCLC of glandular subtype [13]. Usually, the tissue material biopsy is necessary to determine the presence of the mutation. The pilot study by Pu et al. showed that the analysis of typical EGFR mutations in saliva, that is the deletion of exon 19 and mutation of L858R performed utilizing EFIRM method (Electric Field-Induced Release and Measurement) with the application of electric field correlates well with their detection in plasma of patients before as well as after surgery [14]. In a similar study by Wei et al. with the application of the same method in 22 patients with NSCLC in saliva as well as in blood serum, the typical EGFR mutations occurring in lung cancer were detected. The test is quick, non-invasive, low-budget, and highly effective [15]. In literature, there is an acronym SABER (Saliva-based EGFR mutation detection), which refers to the analysis of EGFR gene mutation in saliva [14,15]. Another study showed that saliva contains 16 proteins in 
saliva, which are highly specific to lung cancer patients. Three of them were subsequently detected in lung cancer cell lines. Standard markers of these proteins is distinguished by $88.5 \%$ of sensitivity and $92.3 \%$ of specificity regarding the presence in lung cancer patients [16]. In a study by Li et al., saliva samples collected from lung cancer patients and healthy volunteers through the SERS method (Surface-enhanced Raman Spectroscopy) were analyzed. The intensity of the spectrum of scattered photons which correspond to nucleic acids and proteins was observed. The results showed that in lung cancer patients, there is a significant decrease. A detailed statistical analysis of the obtained data showed accuracy, sensitivity, and specificity amounting to $80 \%, 78 \%$, and $83 \%$, respectively [17]. A study from 2018 confirms, to some extent, the results mentioned above. SERS method was also applied, and significant differences in the intensity of the photon spectrum from tissues, body fluid among lung cancer patients and healthy volunteers were obtained [18].

\section{Prostate cancer}

The measurement of the concentration of Prostate-Specific Antigen (PSA) in peripheral blood is a routine test performed in the course if diagnostic adhesion alterations of the prostate gland. Its increased levels often indicate the possibility of an ongoing malignant process in this organ. Yet, PSA concentration marking as a solitary test has limited value due to low diagnostic specificity, which is in the wide range of 17-61\% [19]. In the clinical practice, PSA marker is often checked with other tests in the first instance with USG of the prostate gland and is helpful in the distinction between benign and malignant variants. In the study by Shiiki et al., the dependence between the PSA concentration in peripheral blood and saliva of patients with prostate adenocarcinoma. Patients were divided into two groups depending on the PSA concentration levels in the blood. The first group $(n=20)$ was characterized by PSA concentration lower than $2.5 \mathrm{ng} / \mathrm{mL}$, whereas in the other group ( $\mathrm{n}=11)$, the PSA concentration was higher than $2.5 \mathrm{ng} / \mathrm{mL}$. The results showed that the PSA concentration in saliva was significantly different in these groups. I correlated well with PSA concentration in blood of patients from the second group that is those whose PSA concentration in blood was higher. Such dependency was not observed in patients from group one.

Study authors report the possibility of the use of non-invasive PSA measurement in the saliva of prostate cancer patients as an effective relapse biomarker [20]. Most recent scientific reports focus on the non-invasive molecular diagnostic of prostate cancer. The detection of specific microRNA (miRNA) fragments circulating in body fluids becomes a factual perspective. The role of miRNA is, first and foremost, the regulation (muffling) gene expression on the post-transcriptional level. It is estimated that around $30 \%$ of human mRNA is strictly regulated by miRNA [21]. It is diagnostically relevant that the miRNA molecules show high stability in body fluids (blood, urine, cerebrospinal fluid) [22]. miR141, miR-21, and mi-R375 are circulating miRNA, which can be detected in the serum of prostate cancer patients. They are regarded as biomarkers of prostate tumor. Their detection in body fluids may be useful for the diagnosis and stage determination of malignancy. These methods are of importance in a very early stage of the disease when performing a biopsy, or PSA measurement does not give any diagnostic answer [23,24]. The increased amount of miR-141 is detected in advanced stages of prostate cancer, while the presence of miR-21 is observed in the early stage of the disease [25]. Moreover, a study conducted in 2017 showed that miR-141 could inhibit progenitor cells of prostate cancer and the formation of metastasis [26].

\section{Breast cancer}

There are many studies on the topic of searching for the most sensitive and specific biomarkers of breast cancer. In the clinical practice, the concentration of Ca15-3 antigen in peripheral blood is often tested should there be any difficulties with a clear evaluation of response to treatment and indirect assessment of the effectiveness of treatment of this cancer. For the same reason, the Carcinoembryonic Antigen (CEA) is tested.

Studies conducted in 2015 show that there is a possibility to mark antibodies against ATPase ATP6AP1, whose presence is characteristic for patients with early-stage breast cancer [27]. A study by Zhang et al. showed that there are significant differences in the number of molecular biomarkers in saliva among patients with breast cancer and control groups. Due to the method of transcriptome and proteomic profiling, eight mRNA biomarkers and one protein biomarker, which may be marked in saliva with the aim of breast cancer detection, were discovered. The sensitivity and specificity of this test amounted to $83 \%$ and $97 \%$, respectively [28]. The study by Brooks et al. showed that the concentration of Vascular Endothelial Growth Factor (VEGF), Epithelial Growth Factor (EGF) and CEA antigen in the saliva is higher in breast cancer patients (the type of breast cancer was not determined) in comparison to healthy individuals [29]. The concentration of Ca15-3 in saliva and serum 
of healthy volunteers and women with I and II stage breast cancer was analyzed. The results showed a positive correlation between the concentration of Ca15-3 antigen in saliva and the stage of the disease. Moreover, a positive correlation occurred between the Ca15-3 concentration in saliva and serum in these patients [30]. A report from 2014 confirmed the previous results [31]. The current studies focus on proteomic tests. Streckfus et al. analyzed the proteomic profile in the saliva of three groups of women. The control group consisted of healthy women. The second group included women with a diagnosed benign breast tumor, while saliva samples of women with diagnosed DCIS (Ductal Carcinoma In Situ) belonged to the third group. 130 proteins were identified in all groups, out of which 49 proteins were characteristic for the second or third group. The study suggests that protein profiles that are unique for DCIS and benign lesions may be present in saliva [32]. Next, research by the same author aimed at the comparison of the protein profile in the saliva of women with invasive breast cancer in the stage without lymph node involvement (IIa) and with lymph node involvement (IIb). A total of 174 proteins were identified, out of which 55 occurred in both stages, while 20 and 28 proteins were specific for IIa and IIb stadium, respectively [33]. Moreover, Streckfus discovered the presence of a soluble form of c-erbB-2 protein in saliva and serum. The author measured the concentration of this protein in saliva in three different groups of women with the application of the ELISA method. The first group consisted of healthy women. The second group included women with benign breast lesions while to the third group belonged women with breast cancer (cancer type was not determined). In order to compare the relative usefulness of the c-erbB-2 protein, the evaluation of Ca15-3 concentration in saliva was conducted. Ca15-3 served as a "golden standard" with which the diagnostic effectivity of c-erbB-2 concentration in saliva and serum was compared. The results showed the presence of c-erbB-2 protein in saliva and serum in all three studied groups. The concentration of c-erbB-2 in saliva and serum in breast cancer patients is significantly higher $(\mathrm{P}<0.001)$ than in the first and second group. The results suggest that the c-erbB-2 protein may be useful in initial detection and/or further screening tests towards the relapse of breast cancer in women [34]. One of the most recent scientific reports from 2015 presents a comparative analysis of the concentration of Lung Resistance Protein (LRP) in saliva among healthy women and those with early-stage (stage I) breast cancer. The analysis of results showed a statistically significant higher concentration of this protein in the saliva of women with breast cancer than in the group of healthy women. Study authors point towards the possibility of using markers of this protein in saliva to detect breast cancer in an early stage [35]. The results of the study mentioned above are promising and give hope for the possibility of future application of saliva in breast cancer diagnostic.

\section{Pancreatic cancer}

Despite newer and more accurate imaging methods, the diagnostic of pancreatic cancer often occurs in the late stages of the disease. This is the result of scarce and non-specific symptoms of the tumor. Therefore, the discovery of diagnostic methods that would be useful in the early stages of pancreatic cancer became a goal for many scientists. Disparate concentration levels of 4 mRNA biomarkers (KRAS, MBD3L2, ACRV1, and DPM1) were shown in saliva in pancreatic cancer patients, healthy individuals, and patients with chronic pancreatitis. The sensitivity and specificity of this test amounted to $90 \%$ and $95 \%$, respectively [36]. In a study by Xie et al., the usefulness of miRNA marker testing in saliva in pancreatic cancer diagnostic was examined. A miRNA profiling with the application of microarray in saliva collected from 8 patients with pancreatic cancer and eight healthy volunteers was conducted. miRNA biomarkers were evaluated in reference to three categories of patients. Results from patients with pancreatic cancer and healthy volunteers were compared. Next, the results of pancreatic cancer patients were compared with the results of patients with a benign lesion in the pancreas, and results of pancreatic cancer patients were compared with joint results obtained from healthy volunteers and patients with a benign lesion in pancreas. The obtained results showed the presence of 2 miRNA biomarkers, which are characteristic of pancreatic cancer, which is miR-3679-5p and miR940. In the group of patients with pancreatic cancer, the amount of the first biomarker was statistically significantly lower. In contrast, the amount of miR940 was considerably higher in comparison to other studied groups. The developed logistic regression models which join two above-mentioned salivary miRNA could differentiate pancreatic cancer in three categories of patients, showing sensitivity and specificity in the range from $62.5 \%$ to $80 \%$. In the study, the authors reported the usefulness of detection of these biomarkers in the saliva of pancreatic cancer patients [37]. There are also correlations between periodontosis and the more frequent occurrence of pancreatic cancer in this group [38]. A different profile of oral cavity microbiota in pancreatic cancer patients was reported. Additionally, two bacteria strains, i.e., Neisseria elongata and Streptococcus mitis, show high sensitivity and specificity in occurrence in patients with pancreatic cancer [39]. 


\section{Conclusions}

Undoubtedly saliva constituted a valuable biological material that contains many substances useful in the diagnostic of selected malignant cancers. Researchers consider the most potential for markers which are associated with the faster referral of urgent diagnosis, in order to exclude cancer. It would be best if those actions were introduced in the presymptomatic stage, that is when the patient does not present distinct clinical symptoms connected with cancer. In such a case, there is still a possibility of radical treatment of specific cancer. The detection of such tests would be significant facilitation and significant acceleration in the diagnostic process. Thus, the therapy could be started much earlier what should result in better results of 5-year survival. The fact that the detection of characteristic substances for specific cancer in saliva can never replace full diagnostic, but it can accelerate it and put it "on the right track" is undeniable. Together with the development of more accurate diagnostic methods and because of the simplicity of biological material collection which is saliva, the repetitiveness of the test, and its availability, it is worth looking in the future with hope for the acceleration of cancer diagnostics.

\section{References:}

1. Sreebny LM. Salivary flow in health and disease. Compend. Suppl. 1989; (13): S461-469.

2. Szydlarska D, Grzesiuk W, Kupstas A, Bar-Andziak E. [Saliva as a diagnostic material]. Forum Medycyny Rodzinnej. 2008; 2(6): 454-464 (in Polish).

3. Khurshid Z, Zafar MS, Najeeb S, Zohaib S. Human saliva: a future diagnostic tool. EC Dental Science. 2016; 3.6: 635-636.

4. Yu M, Zhang X, Yu Q. Detection of oral Helicobacter Pylori infection using saliva test cassette. Pak J Med Sci. 2015; 31(5): 1192-1196. https://doi.org/10.12669/pjms.315.7626

5. Ochnio JJ, Scheifele DW, Ho M, Mitchell LA. New, ultrasensitive enzyme immunoassay for detecting vaccineand disease-induced hepatitis A virus-specific immunoglobulin G in saliva. J. Clin. Microbiol. 1997; 35(1): 98-101. https://doi.org/10.1128/JCM.35.1.98-101.1997

6. El-Medany OM, El-Din Abdel Wahab KS, Abu Shady EA, Gad El-Hak N. Chronic liver disease and hepatitis C virus in Egyptian patients. Hepatogastroenterology. 1999; 46(27): 1895-1903.

7. Hettegger P, Huber J, Paßecker K, Soldo R, Kegler U, Nöhammer C, et al. High similarity of IgG antibody profiles in blood and saliva opens opportunities for saliva based serology. PLoS One. 2019; 14(6): e0218456. https://doi.org/10.1371/journal.pone.0218456

8. Martinez PM, Torres AR, Ortiz de Lejarazu R, Montoya A, Martín JF, Eiros JM. Human immunodeficiency virus antibody testing by enzyme-linked fluorescent and western blot assays using serum, gingival-crevicular transudate, and urine samples. J Clin Microbiol. 1999; 37(4): 1100-1106.

https://doi.org/10.1128/JCM.37.4.1100-1106.1999

9. www.fda.gov. OraQuick ADVANCE® Rapid HIV-1/2 Antibody Test package insert [Internet]. Silver Spring: FDA [cited 2020 March 20]. Available from: https://www.fda.gov/files/Control-Kit---OraQuick-Rapid-HIV-12-Antibody-Test.pdf

10. Didkowska J, Wojciechowska U, Czaderny K, Olasek P, Ciuba A. Cancer in Poland in 2017. Warszawa: Ministry of Health; 2019. p. 9-15.

11. Doebele RC, Oton AB, Peled N, Ross Camidge D, Bunn Jr. PA. New strategies to overcome limitations of reversible EGFR tyrosine kinase inhibitor therapy in non-small cell lung cancer. Lung Cancer. 2010; 69(1): 1-12. https://doi.org/10.1016/j.lungcan.2009.12.009

12. Potempa M, Jonczyk P, Zalewska-Ziob M. [Molecular determinants of lung cancer]. Onkol. Prak. Klin. 2014; 10(4): 199-211 (in Polish).

13. Szumera-Ciećkiewicz A, Olszewski WT, Tysarowski A, Kowalski DM, Głogowski M, Krzakowski M, et al. EGFR mutation testing on cytological and histological samples in non-small cell lung cancer: a Polish, single institution study and systematic review of European incidence. Int. J. Clin. Exp. Pathol. 2013; 6(12): 28002812.

14. Pu D, Liang H, Wei F, Akin D, Feng Z, Yan Q, et al. Evaluation of a novel saliva-based epidermal growth factor receptor mutation detection for lung cancer: a pilot study. Thorac Cancer. 2016; 7(4): 428-436. https://doi.org/10.1111/1759-7714.12350

15. Wei F, Lin CC, Joon A, Feng Z, Troche G, Lira ME, et al. Noninvasive saliva-based EGFR gene mutation detection in patients with lung cancer. Am J Respir Crit Care Med. 2014; 190(10): 1117-1126.

https://doi.org/10.1164/rccm.201406-10030C 
16. Xiao H, Zhang L, Zhou H, Lee JM, Garon EB, Wong DT. Proteomic analysis of human saliva from lung cancer patients using two-dimensional difference gel electrophoresis and mass spectrometry. Mol Cell Proteomics. 2012; 11(2): M111.012112. https://doi.org/10.1074/mcp.M111.012112

17. Li X, Yang T, Lin J. Spectral analysis of human saliva for detection of lung cancer using surface-enhanced Raman spectroscopy. J Biomed Opt. 2012; 17(3): 037003. https://doi.org/10.1117/1.JB0.17.3.037003

18. Qian K, Wang Y, Hua L, Chen A, Zhang Y. New method of lung cancer detection by saliva test using surfaceenhanced Raman spectroscopy. Thorac Cancer. 2018; 9(11): 1556-1561. https://doi.org/10.1111/17597714.12837

19. Rychlik U, Tarapacz J, Jaszczyński J, Jakubowicz J, Kulpa JK. [Complexed PSA in prostate cancer patients with total PSA ranging between 2.0-20.0 ng/mL]. Journal of Laboratory Diagnostics. 2009; 45(1): $41-48$ (in Polish).

20. Shiiki N, Tokuyama S, Sato C, Kondo Y, Saruta J, Mori Y, et al. Association between saliva PSA and serum PSA in conditions with prostate adenocarcinoma. Biomarkers. 2011; 16(6): 498-503. https://doi.org/10.3109/1354750X.2011.598566

21. Świtlik W, Szemraj J. [Circulating miRNAs as non-invasive biomarkers for non-small cell lung cancer diagnosis, prognosis and prediction of treatment response]. Postepy Hig Med Dosw (online). 2017; 71: 649661 (in Polish). https://doi.org/10.5604/01.3001.0010.3845

22. Gilad S, Meiri E, Yogev Y, Benjamin S, Lebanony D, Yerushalmi N, et al. Serum microRNAs are promising novel biomarkers. PLoS One. 2008; 3(9): e3148. https://doi.org/10.1371/journal.pone.0003148

23. Bryant RJ, Pawlowski T, Catto JWF, Marsden G, Vessella RL, Rhees B, et al. Changes in circulating microRNA levels associated with prostate cancer. Br J Cancer. 2012; 106(4): 768-74. https://doi.org/10.1038/bjc.2011.595

24. Porzycki P, Ciszkowicz E, Semik M, Tyrka M. Combination of three miRNA (miR-141, miR-21, and miR-375) as potential diagnostic tool for prostate cancer recognition. Int Urol Nephrol. 2018; 50(9): 1619-1626. https://doi.org/10.1007/s11255-018-1938-2

25. Hizir MS, Balcioglu M, Rana M, Robertson NM, Yigit V. Simultaneous detection of circulating oncomiRs from body fluids for prostate cancer staging using nanographene oxide. ACS Appl Mater Interfaces. 2014; 6(17): 14772-14778. https://doi.org/10.1021/am504190a

26. Liu C, Liu R, Zhang D, Deng Q, Liu B, Chao H, et al. MicroRNA-141 suppresses prostate cancer stem cells and metastasis by targeting a cohort of pro-metastasis genes. Nature Communications. 2017; 8(14270): 1-14. https://doi.org/10.1038/ncomms14270

27. Arif S, Qudsia S, Urooj S, Chaudry N, Arshad A, Andleeb S. Blueprint of quartz crystal microbalance biosensor for early detection of breast cancer through salivary autoantibodies against ATP6AP1. Biosens Bioelectron. 2015; 65: 62-70. https://doi.org/10.1016/j.bios.2014.09.088

28. Zhang L, Xiao H, Karlan S, Zhou H, Gross J, Elashoff D, et al. Discovery and preclinical validation of salivary transcriptomic and proteomic biomarkers for the non-invasive detection of breast cancer. PLoS One. 2010; 5(12): e15573. https://doi.org/10.1371/journal.pone.0015573

29. Brooks MN, Wang J, Li Y, Zhang R, Elashoff D, Wong DT. Salivary protein factors are elevated in breast cancer patients. Mol Med Rep. 2008; 1(3): 375-378. https://doi.org/10.3892/mmr.1.3.375

30. Agha-Hosseini F, Mirzaii-Dizgah I, Rahimi A. Correlation of serum and salivary CA15-3 levels in patients with breast cancer. Med Oral Patol Oral Cir Bucal. 2009; 14(10): e521-e524. https://doi.org/10.4317/medoral.14.e521

31. Laidi F, Bouziane A, Lakhdar A, Khabouze S, Amrani M, Rhrab B, et al. Significant correlation between salivary and serum Ca 15-3 in healthy women and breast cancer patients. Asian Pac. J. Cancer Prev. 2014; 15(11): 4659-4662. https://doi.org/10.7314/APJCP.2014.15.11.4659

32. Streckfus CF, Mayorga-Wark O, Arreola D, Edwards C, Bigler L, Dubinsky WP. Breast cancer related proteins are present in saliva and are modulated secondary to ductal carcinoma in situ of the breast. Cancer Investig. 2008; 26(2): 159-167. https://doi.org/10.1080/07357900701783883

33. Streckfus CF, Storthz KA, Bigler L, Dubinsky WP. A comparison of the proteomic expression in pooled saliva specimens from individuals diagnosed with ductal carcinoma of the breast with and without lymph node involvement. J. Oncol. 2009; 2009: 737619. https://doi.org/10.1155/2009/737619

34. Streckfus CF, Bigler L, Dellinger TD, Dai X, Kingman A, Thigpen JT. The presence of c-erbB-2, and CA 15-3 in saliva and serum among women with breast carcinoma: a preliminary study. Clin. Can. Res. 2000; 6(6): 2363-2370.

35. Wood N, Streckfus CF. The expression of lung resistance protein in saliva: a novel prognostic indicator protein for carcinoma of the breast. Cancer Investig. 2015; 33(10): 510-515.

https://doi.org/10.3109/07357907.2015.1081920 
36. Zhang L, Farrell JJ, Zhou H, Elashoff D, Akin D, Park NH, et al. Salivary transcriptomic biomarkers for detection of resectable pancreatic cancer. Gastroenterology. 2010; 138(3): 949-57. https://doi.org/10.1053/j.gastro.2009.11.010

37. Xie Z, Yin X, Gong B, Nie W, Wu B, Zhang X, et al. Salivary microRNAs show potential as a noninvasive biomarker for detecting resectable pancreatic cancer. Cancer Prev Res (Phila). 2015; 8(2): 165-173. https:// doi.org/10.1158/1940-6207.CAPR-14-0192

38. Michaud DS, Izard J. Microbiota, oral microbiome, and pancreatic cancer. Cancer J. 2014; 20 (3): $203-206$. https://doi.org/10.1097/PP0.0000000000000046

39. Farrell JJ, Zhang L, Zhou H, Chia D, Elashoff D, Akin D, et al. Variations of oral microbiota are associated with pancreatic diseases including pancreatic cancer. Gut. 2012; 61(4): 582-588.

https://doi.org/10.1136/gutjnl-2011-300784 